\title{
LINEAR PROGRAMMING : A BOON FOR FARMERS
}

\author{
Harleen Kaur \\ Department of Mathematics \\ Chandigarh University, Mohali, Punjab, India
}

\author{
Nishi Gupta \\ Department of Mathematics \\ Chandigarh University, Mohali, Punjab, India
}

\begin{abstract}
As we all know that condition of most farmers especially in India is horrible. The agriculture supports nearly 50 percent [2] of the employment but contributes only 15 percent to the Gross Domestic Product (GDP). Every day there is news coming on farmers suicides from different parts of the country. We should start thinking about farmers and their families and must try to find out different ways to help them. Nowadays, due to some policies taken by Indian Government, Indian farmers are massively coming together against these policies issued by government (against privatization) [4]Linear Programming can help them a lot to improve their condition. They will came to know which crop and in how much quantity they should plant their crop to earn maximum profit.
\end{abstract}

Keywords - Feasible region, feasible solution, optimal solution, optimal value

\section{INTRODUCTION}

Here are some of the examples where using LP is so much beneficial : Just think of a bakery which is in loss just because the workers and the owner of that bakery does not know that in how much quantity of food item they should produce and how much raw material is required[5].A small company which is not flourishing much because it does not know how many employees are required to achieve its targets. We just want best in less time and resources .Even when we move out of our house to reach our destination we all use google maps to get the shortest route to reach our destination.[1]A factory which is flourishing day by day because it knows how many workers and in which quantity of raw material is required to make a product. [8] Think of a transportation company who knows the best routes to transport products from different sources to different destinations so that transportation cost is minimum.[2-5]. In all above examples what do you think how the factory owner and the transportation owner knows that how many workers[11] and how much quantity of raw material are required and what are the strategies used by transportation owner.They are using linear programming.

\section{PROPOSED ALGORITHM}

\section{A. Mathematical form of Linear Programming --}

Basically the use of linear programming is optimization of resources that is maximize our profit and minimize the cost (or
time).From a small business to a big business ,from morning to evening in our daily life, everywhere we are using optimization. [2]LPP is the programming of allocation of limited resources subject to some constraints. Programming problems are optimization (maximization or minimization) problems. [8]Here we optimize $\mathrm{Z}$ (an objective function) that is subject to constraints .It also includes the variables that satisfy non negative constraints .So, an LPP has an objective function constraints (which may be equalities or inequalities) and non - negative condition[12] .General LPP can be written as:

$\operatorname{Max} / \operatorname{Min} z=\mathbf{c}_{1} \mathbf{x}_{1}+\mathbf{c}_{2} \mathbf{x}_{2}+\ldots+\mathbf{c}_{\mathbf{n}} \mathbf{x}_{\mathbf{n}}$

subject to (s. t.)

$\mathbf{a}_{11} \mathbf{x}_{1}+a_{12} x_{2}+\ldots \ldots+a_{1 n} x_{n}(\geq$ or $=$ or $\leq) b_{1}$

$\mathbf{a}_{21} \mathbf{x}_{1}+a_{22} x_{2}+\ldots . .+a_{2 n} x_{n}(\geq$ or $=$ or $\leq) \mathbf{b}_{2}$

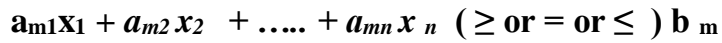

$\mathrm{x}_{\mathrm{j}} \geq \mathbf{0}$ for all $\mathrm{j}=1,2,3, \ldots, \mathrm{n}$

$c_{1}, c_{2}, \ldots . . . c_{n} \quad$ cost coefficients

$\mathrm{b}_{1}, \mathrm{~b}_{2}, \ldots . . . \mathrm{b}_{\mathrm{n}} \quad$ decision variables

$x_{1}, x_{2}, \ldots, x_{n} \quad$ required coefficients

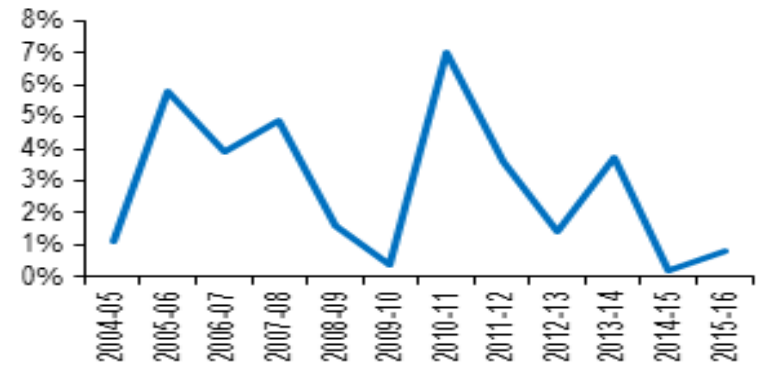

Fig. 1. Growth in agriculture sector (\%) 


\section{International Journal of Engineering Applied Sciences and Technology, 2021 \\ Vol. 5, Issue 12, ISSN No. 2455-2143, Pages 223-226 \\ Published Online April 2021 in IJEAST (http://www.ijeast.com)}

\section{B. Some Important terms --}

- Feasible Solution: The value of $(\mathrm{x}, \mathrm{y})$ that satisfies all constraints and non-negativity condition is called feasible solution.[7]

- Feasible Region : Set of all feasible solutions i.e. All the values $(\mathrm{x}, \mathrm{y})$ that satisfies all constraints and non-negativity condition.

- Optimal Solution : A feasible solution that optimizes the objective function is an optimal solution.

- Optimal Value: The value of the objective function at the optimal solution.[9]

\section{EXPERIMENT AND RESULT}

A farmer has 150 hectares piece of land. He decided to grow wheat and rice on that 150 hectares of land. He wants to know how to plant each variety in the 150 hectares.

Here is the data:

Table-1 Wheat and Rice infomation

\begin{tabular}{|c|c|c|c|}
\hline Crop & $\begin{array}{c}\text { Cost per } \\
\text { hectare }\end{array}$ & $\begin{array}{c}\text { Days Labor } \\
\text { take per } \\
\text { hectare }\end{array}$ & $\begin{array}{c}\text { Total profit } \\
\text { per hectare }\end{array}$ \\
\hline Wheat & 300 & 20 & 800 \\
\hline Rice & 100 & 50 & 1200 \\
\hline
\end{tabular}

Farmer's budget $=80000$

Labor days (Man days $)=1200$

To find

(i) optimal value

(ii) optimal solution

\section{Steps to solve this problem:}

\section{Step 1: Identifying decision variables}

Let area for growing crop1 (Wheat) is $\mathrm{X}$ (in hectares)

And area for growing crop2 (Rice) is Y (in hectares)

where $\mathrm{X}$ and $\mathrm{Y}$ are the decision variables.

Step 2: This step involves finding (writing) objective function.

Given : profit for wheat $=$ Rs. 800 per hectare

Profit for rice $=$ Rs. 1200 per hectare
Objective function :

$\operatorname{Max} Z=800 X+1200 Y$

Step 3: This step involves finding(or writing) the constraints: [4]

Given: Farmer's total budget : Rs. 80,000

Also Given: per hectare cost ( for producing rice and wheat)

So, constraint 1 is given by:

$300 \mathrm{X}+100 \mathrm{Y} \leq 80,000$

Given: Labour(Man) days $=1200$.

Now using above information, next constraint is :

$20 \mathrm{X}+50 \mathrm{Y} \leq 1200$

Given: Total Area $=150$ hectares

So the last constraint is:

$\mathrm{X}+\mathrm{Y} \leq 150$

Step 4: The non-negative condition[7]:

As $\mathrm{X}$ is area for growing crop1 (Wheat) and $\mathrm{Y}$ is area for growing crop2(Rice) .

Area can not be negative .So, both $\mathrm{X}$ and $\mathrm{Y}$ must be $\geq 0$.

$\mathrm{X} \geq 0, \mathrm{Y} \geq 0$

So, these are the steps involved to solve this problem.

\section{Graphical Solution:}

After solving we get:

Table-2 Experiment Result

\begin{tabular}{||c|c|c|}
$\begin{array}{c}\text { Extreme Point } \\
\text { Coordinates } \\
\left(x_{1}, x_{2}\right)\end{array}$ & Lines through Extreme Point & $\begin{array}{c}\text { Objective function value } \\
Z=800 x_{1}+1200 x_{2}\end{array}$ \\
\hline$O(0,0)$ & $\begin{array}{c}4-x_{1} \geq 0 \\
5-x_{2} \geq 0\end{array}$ & $800(0)+1200(0)=0$ \\
\hline$A(60,0)$ & $\begin{array}{c}20 x_{1}+50 x_{2} \leq 1200 \\
5-x_{2} \geq 0\end{array}$ & $800(60)+1200(0)=48000$ \\
\hline$B(0,24)$ & $2-\begin{array}{c}20 x_{1}+50 x_{2} \leq 1200 \\
4-x_{1} \geq 0\end{array}$ & $800(0)+1200(24)=28800$ \\
\hline
\end{tabular}

The values of $\mathrm{Z}$ at extreme points $\mathrm{O}, \mathrm{A}$ and $\mathrm{B}$ are : 


$$
\begin{array}{ll}
\text { At } \mathrm{O}(0,0) & =0 \\
\text { At } \mathrm{A}(60,0) & =48,000 \\
\text { At B }(0,24) & =28,800
\end{array}
$$

This is the graph

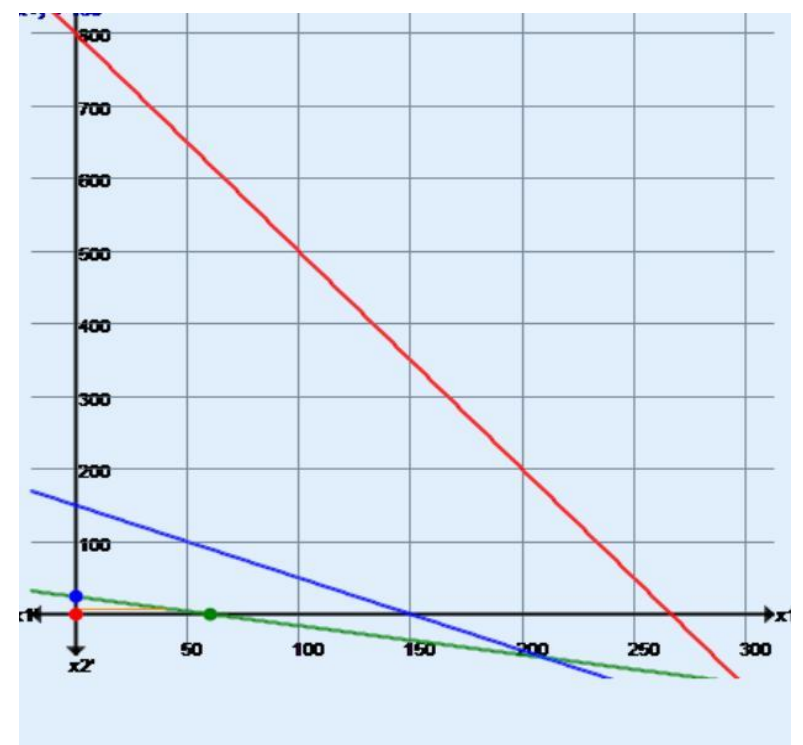

The maximum value of the objective function $Z=48000$ occurs at the extreme point $(60,0)$.Hence, the optimal solution to the given LP problem is: $X 1=60, X 2=0$ and $\max Z=48000$.Total area for growing wheat is 60 hectares and for rice is 0 hectare.

To solve this problem in $\mathrm{R}$, we have install a package "lpSolve".[6]

This is the solution using $\mathrm{R}$ software.

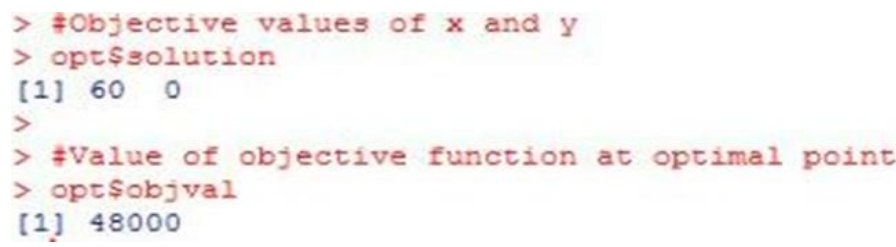

\section{Problem 2:}

Let's look at a simple LP model for a small farm with the following details.[4]

Each year, four crops can be grown: jeera, wheat, mung, and cotton. Each has its own set of labour and mules specifications per hector.

Table-3 Information regarding crops

\begin{tabular}{|l|l|l|l|l|l|} 
CROPS & Jeera & Wheat & Mung & cotton & RHS \\
\hline $\begin{array}{l}\text { Objective } \\
\text { Function(pesos) }\end{array}$ & 1372 & 1219 & 1523 & 4874 & maximize \\
\hline Land(ha) & 0 & 0 & 0 & 1 & $\leq 5.0$ \\
\hline Labor (months) & 1.42 & 1.87 & 1.92 & 2.64 & $\leq 16.5$ \\
\hline Mules (months) & 1.45 & 1.27 & 1.16 & 1.45 & $\leq 10.0$ \\
\hline $\begin{array}{l}\text { Market } \\
\text { Constraint (tons) }\end{array}$ & - & - & - & 0.983 & $\leq 0.5$ \\
\hline
\end{tabular}

The amount of labour given by family workers over the course of the year could amount to a number of months. [2] The farm family owns a mule (draught animal services) that will provide draught control for 10 months of the year.

Let $\mathrm{X} 1=$ jeera, $\mathrm{X} 2=$ wheat, $\mathrm{X} 3=$ mung, and $\mathrm{X} 4=$ cotton be the inputs to the model.

Max $Z=1372 X_{1}+1219 X_{2}+1523 X_{3}+4874 X_{4}$

Sub to Constraints:

$1 \mathrm{X}_{4} \leq 5$

$1.42 \mathrm{X}_{1}+1.87 \mathrm{X}_{2}+1.92 \mathrm{X}_{3}+2.64 \mathrm{X}_{4} \leq 16.5$

$1.45 \mathrm{X}_{1}+1.27 \mathrm{X}_{2}+1.16 \mathrm{X}_{3}+1.45 \mathrm{X}_{4} \leq 10.0$

$0.983 \mathrm{X}_{4} \leq 0.5$

$$
\mathrm{X}_{1}, \mathrm{X}_{2}, \mathrm{X}_{3}, \mathrm{X}_{4} \geq 0
$$

$X_{1}=$ jeera $=1.02 /$ ha wheat $=0 \quad X_{2}==$ mung $=7.14 /$ ha $X_{3} 0.50 /$ ha $\mathrm{X}_{4}=$ cotton is the best answer.

\section{Problem 3}

\section{Fertilizer Mix Problem}

Super-Gro and Crop-Quick are two fertiliser brands that are accessible. [7]A minimum of 16 gramme of nitrogen and 24 gramme of phosphorus are needed in the field. Super-Gro costs Rs6 per bag, while Crop-Quick costs Rs3. Given the following information, how much of each brand should be purchased to reduce overall fertiliser costs?

Table - 4 Chemical contribution information

\begin{tabular}{c|c|c|}
\hline \multicolumn{3}{|c|}{ Chemical contribution } \\
\hline Brand & $\begin{array}{c}\text { Nitrogen } \\
\text { (gram/bag) }\end{array}$ & $\begin{array}{c}\text { Phosphate } \\
\text { (gram/bag) }\end{array}$ \\
\hline Super-gro & 2 & 4 \\
\hline Crop- quick & 4 & 3 \\
\hline
\end{tabular}

The model's formulation

Consider the decision variables $\mathrm{X}_{1}$ and $\mathrm{X}_{2}$.

$\mathrm{X}_{1}=$ Super-Gro bags

$\mathrm{X}_{2}=$ Crop-Quick bags

The Role of the Objective:

Reduce to a bare minimum $6 \mathrm{X}_{1}+3 \mathrm{X}_{2}=\mathrm{Z}$

Constraints imposed: 


\section{International Journal of Engineering Applied Sciences and Technology, 2021 \\ Vol. 5, Issue 12, ISSN No. 2455-2143, Pages 223-226 \\ Published Online April 2021 in IJEAST (http://www.ijeast.com)}

$16<=2 \mathrm{X}_{1}+4 \mathrm{X}_{2}$ (nitrogen constraint)

$24<=4 X_{1}+3 X_{2}$ (phosphate constraint)

$\mathrm{X}_{1}>=0, \mathrm{X}_{2}>=0, \mathrm{X}_{3}>=0, \mathrm{X}_{4}>=0$

(Constraint of non-negativity)

The best option is to

$\mathrm{X}_{1}=6=$ Super-Gro bags (gram).

\section{CONCLUSION}

In problem 1 , The farmer should plant wheat in 60 hectares of land. He should not plant rice in that land. He will earn a profit of rupees 48000 . So, the problem which was defined above is solved now. It sounds strange that the farmer should use only in 60 hectares of land out of 120 hectares of land but if he use rest of the land for planting rice then it will not be beneficial for him. Linear Programming gives best solution in limited resources. So, if Linear Programming is used in farming sector then the day is not so far when there will be no case of any suicides by any farmer and our country India will become "Sone ki Chidiya" again.

\section{REFERENCE}

[1] Sallan, J.M., Lordan, O., Fernandez, V. (2015): Modeling and solving linear programming with $\mathrm{R}$. Universitat Politècnica de Catalunya , DOI: http://dx.doi.org/10.3926/oss.20 .

[2] VICO Grujica, BODIROGA Radomir ,2017, Tools for planning in agriculture - Linear programming approach, DOI:10.13140/RG.2.2.31748.22405.

[3] CALDWELL H.W., 1956,AN APPLICATION OF LINEAR PROGRAMMING TO FARM PLANNING, DOI: https://doi.org/10.1111/j.1744-7976.1956.tb01076.

[4] Lazzerini B. and Pistolesi F. ,(2014), "Neural network-based objectivesprioritization for multiobjective economic dispatch in microgrids,"in Proc. IEEE/SICE Int. Symp. on System Integration (SII2014), Tokyo, JP, pp. 665671.,DOI:http://dx.doi.org/10.13140/2.1.5142.096

[5] F M Zenis1, S Supian2, E Lesmana2,2017, Optimization of land use of agricultural farms in Sumedang regency by using linear programming models, doi:10.1088/1757-899X/332/1/012021.

[6] Butterworth Keith ,2017,Practical Application of Linear/Integer Programming in Agriculture,doi: https://doi.org/10.1057/jors.1985.22

[7] Bhatia Mahak, Rana Anil,2020,Mathematical Approach to Optimize Crop Allocation - A Linear Programming Model,DOI: https://doi.org/10.18280/ijdne.150215
[8] Dury, J., Schaller, N., Garcia, F., Reynaud, A., Bergez, J.E. (2012). Models to support cropping plan and crop rotation decisions. A review. Agronomy for Sustainable Development, 32(2): 567-580. https://doi.org/10.1007/s13593-011-0037$\mathrm{x}$

[9] Hj. Nordin Mahomad and Said Fatimah ,2011 Mathematical Programming approach to crop mix problem

."African Journal of Agricultural Research.Vol.6(1), pp. 191- 197.Retrieved from:DOI: 10.5897/AJAR10.028

[10] Nevo, A., Oad, R., Podmore, T.H. (1994). An integrated expert system for optimal crop planning. Agricultural Systems, 45(1): 73-92. https://doi.org/10.1016/S0308-521X(94)90281-X

[11] Sabouni, M.S., Mardani, M. (2013). Application of robust optimization approach for agricultural water resource management under uncertainty. Journal of Irrigation and Drainage Engineering, 139(7): 571$581 . \quad$ https://doi.org/10.1061/(ASCE)IR.19434774.0000578.

[12] Pap, Z. (2008, September). Crop rotation constraints in agricultural production planning. In Intelligent Systems and Informatics, 2008. SISY 2008. 6th International 